\title{
Insulins as Drugs or Biologics in the USA: What Difference Does it Make and Why Does it Matter?
}

\author{
Kelly George ${ }^{1} \cdot$ Gillian Woollett ${ }^{2}$ (C)
}

Published online: 6 August 2019

(c) The Author(s) 2019

\begin{abstract}
The status of insulins in the USA is about to change as a regulatory matter. After 23 Mar 2020 they, and other hormone products previously regulated as drugs by the US Food and Drug Administration (FDA), even though biologics in science, will become biologics as a regulatory matter too and will be licensed under the Public Health Service Act. This has a number of ramifications for sponsors, patients, and their physicians.
\end{abstract}

\section{Key Points}

The insulins are well-established products that have been regulated by the US Food and Drug Administration (FDA) for many decades; however, their regulatory status will change on 23 March 2020 as a matter of law, even though the products themselves will stay the same.

The FDA will oversee the changes and try to minimize any disruptions in supply. Nonetheless, all stakeholders, especially patients and their healthcare providers as well as those throughout the supply chain, need to understand that the labels of these critical life-saving medicines will change.

Biosimilars to the insulins are unlikely before 2021, and none of the currently approved insulins will be designated as interchangeable. As such, increased competition will likely be delayed by this transition and not enhanced.
Gillian Woollett

gwoollett@avalere.com

1 Avalere Health LLC, 1350 Connecticut Avenue, NW, Washington, DC 20036, USA

2 FDA Policy, Avalere Health LLC, Washington, DC, USA

\section{Background and Introduction}

Insulin is generally regarded as an 'old' product; it was discovered in 1921 and animal-sourced until 1982, when human insulin was the first product brought to market using recombinant DNA technology. Subsequently, analogs have been designed with specific desired clinical properties. For all insulins, monitoring in individual patients must occur multiple times a day and doses need to be carefully titrated to avoid life-threatening variations in blood sugar levels. With one in 12 adults affected [1], insulin is one of the most commonly used biological medicines worldwide.

Insulin is used to treat diabetes mellitus, which itself has two major forms:

- Type 1: formerly called juvenile-onset or insulin-dependent; and

- Type 2: formerly called adult-onset but is not always insulin dependent.

The incidence of diabetes is increasing worldwide, especially type 2 , which is estimated to be the seventh leading cause of death $[1,2]$. Historically, unlike many other specialty medicines, the drug cost has been a comparatively low part of the total cost of care for patients with diabetes. This has been changing in the USA over recent years and the cost of insulin, especially for the uninsured, is now a subject of active discussion in the midst of the broader drug pricing debates [3]. 
Fig. 1 Multiple regulatory pathways are available for the approval of drugs and biologics in the USA. The sponsor elects the pathway to pursue, but usually does so subject to the advice of the US Food and Drug Administration (FDA) throughout development

\section{US STATUTE}

\author{
U.S. Food Drug \& \\ Cosmetic Act \\ [FFDCA]
}

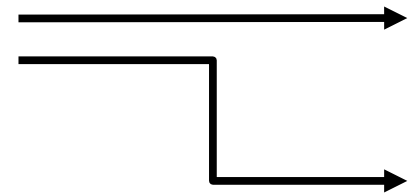

U.S Public Health Service Act [PHSA]
REGULATORY PATHWAY

New Drug

Application (NDA) -

505(b)(1) and 505(b)(2) ${ }^{1}$

PMA and $510 k^{2}$

Generic Drugs

Abbreviated NDA

(505(j) or ANDA)

Biologic License Application (BLA)

or "Standalone" 351(a)

Biosimilar BLA

$(351(k))^{3}$

(Can Be Interchangeable)

Hatch Waxman Act 1984 created the 505(b)(2) and 505(j) generic drug pathways

Premarket Authorization (PMA) and 510K apply to medical devices - these are often used in combination with drugs and biologics . Biologics Price Competition and Innovation Act (BPCIA) is part of the Patient Protection and Affordable Care Act of 2010 (PPACA, ACA or "Obama Care") and created the biosimilar and interchangeable biologics pathways, both are 351(k)

\section{Regulatory History of Insulin in the USA}

Insulin has always been a biologic, as a scientific matter, and was originally isolated from pigs and cows [4]. The first identity and quality standard became available from the United States Pharmacopeia (USP) in 1941 [5, 6], ${ }^{1}$ predating the Federal Food Drug and Cosmetic Act (FFDCA) as we now know it. Even when it became available as a recombinant product in 1982 [7, 8], the US Food and Drug Administration (FDA or the Agency) regulated insulin as a drug under Section 505 of the FFDCA, rather than as a biologic under the Public Health Service Act (PHSA). Largely, this was a simple reflection of where the expertise at the FDA could be found. Back in the early 1980s, the distinctions between the FFDCA and PHSA were not the subject of much interest (being before the Hatch-Waxman Act [9] and generic drugs meant there were few issues around exclusivity and patent listings). The insulins are well-understood analytically, and they are dosed using international units because the amount of protein and level of clinical activity have a direct relationship. Unique among the highly regulated markets, some insulins in the USA are available over the counter. They are also self-administered and patients need to be well-informed as to any changes.

As part of the Affordable Care Act (ACA) [10], also known as 'Obama Care', Title VII is the Biologics Price Competition and Innovation Act (BPCIA). In BPCIA the insulins, along with a number of other products, will be

\footnotetext{
${ }^{1}$ An insulin standard was first published as "Insulin Injection" in United States Pharmacopeia Version XI (USPXI) S2 and became official on 23 December 1941. An official insulin standard was issued in the USP's Interim Revision Announcement No. 4
}

'deemed' to be biologics [11, 12]. That is, after 23 March 2020 all insulins will be licensed under the PHSA rather than under the FFDCA [11, 13] (see Fig. 1). This transfer will entail a number of regulatory changes, such as labeling, but the products themselves will remain the same. Nonetheless, the pathway through which follow-on products can get approved and substituted will be impacted. The FDA has issued a number of guidances for manufacturers outlining the Agency's plans for how the transfer will occur [14].

The FDA held a Part 15 public hearing specific to insulin products on 13 May 2019 and opened a docket for additional comments [15]. While insulins are not the only products to be impacted [16], they will likely be the ones that affect the most patients. As such, it will be important that patients and their healthcare providers understand what is happening [4]. Given they are dispensed in retail pharmacies, questions will also arise as to the relationship between insulins, especially if any are designated as interchangeable in the future. However, the FDA has said that all currently approved insulins will become standalone 351(a) Biologic License Applications (BLAs) [11], and so issues of substitution will not arise immediately. In the USA, substitution of biologics is the same as therapeutic equivalence of drugs, namely it is a regulatory term that allows so designated products to be switched by other than the original prescriber. This is usually a pharmacist (subject to state law). The FDA has recently issued final guidance on interchangeability for biologics [17], but a product must be biosimilar for such a designation to be assigned. No insulin products can be reference products for biosimilars before 23 March 2020. 


\section{Insulins in the USA that Will be 'Rolled Over' on 23 March 2020}

The first recombinant product in the USA was human insulin (also approved in the same year in Europe) [18, 19]. Humulin ${ }^{\circledR}$ (insulin recombinant human), was approved in 1982 as a 505(b)(1) New Drug Application (NDA) [7]. Subsequently, multiple insulin products have been approved, some as analogs, e.g., Humalog ${ }^{\circledR}$ (insulin lispro recombinant) and Lantus ${ }^{\circledR}$ (insulin glargine recombinant), and others as combinations of more than one form [20]. One of the most recent approvals, namely Basaglar ${ }^{\circledR}$ (insulin glargine) was approved as a 505(b)(2) NDA with Lantus ${ }^{\circledR}$ as the reference product. There are no FDA-approved generic insulins [Abbreviated New Drug Application (ANDA) under section 505(j) of FFDCA], nor are any of the 505(b)(2) applications for any of the rollover products designated as therapeutically equivalent to their reference. Meanwhile, we are also seeing new presentations, including combinations with devices-pens and pumps-many with the objective of better blood sugar control as well as greater patient convenience. Given the need to manage blood glucose levels actively, a lot of these drug device combinations are not changing the underlying drug substance or drug product, but are attempting to manage dosing in real time for the patient. The device plus insulin is a combination product [21], and not all insulins can be used with all devices. Often the intellectual property considerations for the devices are quite different, and the patents more recent.

The FDA has indicated that all 'rollover' drug products [16], including all of the insulins, will be designated as standalone 351(a) BLAs on 23 March 2020 when the transition occurs. None will become biosimilars. Hence, none will become interchangeable biologics either, given that those must be designated as biosimilar in order to qualify. However, where they exist, all other quality manufacturing and identity standards will apply; for example, the USP has five drug substance monographs for insulin and 13 drug product monographs, each with accompanying reference standards [22]. Likewise, this also applies for manufacturing requirements, such as Current Good Manufacturing Practices (CGMPs) and Pre Approval Inspections (PAIs), as well as the need for an establishment license.

Meanwhile, the FDA has changed its position on the nonproprietary names that are to be given to the rollover products. In their January 2017 Final Guidance, Nonproprietary Naming of Biological Products (which is no longer available electronically), the FDA indicated that all biologics would be given suffixes to their core name (also known as
International Nonproprietary Names [INN] [23] or United States Adopted Names [USAN] [24] ${ }^{2}$ ) to create the proper name. The USAN is a system whereby the American Medical Association (AMA), American Pharmacists Association (APhA), FDA, and USP agree on the nonproprietary name for all drugs and biologics in the USA and this becomes the name in the USP National Formulary [25], itself recognized by the FDA. The FDA policy for biologics changed with the issuance of their new draft guidance Nonproprietary Naming of Biological Products on 8 March 2019 [26]; this suggests that the proper names of the rollover products will not contain a suffix even when a number of products share the core name [27]. However, rather incongruously, future biosimilars to those rollovers are expected to get suffixes.

Nonetheless, the labels of all the rollover products will change. The FDA has suggested that the labeling changes will be minimal [28]. However, that raises the questions as to if, and if so how, the same insulin product with two different labels will be allowed on the market concurrently at various stages throughout the supply chain from manufacturer to patient. This will be important to consider as it will necessitate each step being able to accommodate duplicate data entries for the same product. The alternative is to make a clean transition at midnight on 23 March 2020, but the wastage of insulin product would be considerable, and the concern created amongst patients and their health providers likely unacceptable.

\section{Dead Zone and Gap Year}

In principle, the rollover looks simple because all the insulin products themselves can be expected to stay the same. However, the FDA has said that a tentative approval of an insulin before 23 March 2020 does not convert to an approval under Section 351, and this creates a dead zone in further 505 NDA applications through that date. Plus, because no 351(a) reference product (required under the BPCIA for a biosimilar or an interchangeable biologic to be developed and an application to be filed at the FDA [29]) for a biosimilar will exist before that date, we can have no 351(k) BLAs either. This creates a gap year after 23 March 2020 before a biosimilar can be approved. The review clock for originator BLAs, as well as for biosimilar and interchangeable biologics, is 12 months (each with a 60-day initial window in which the FDA can Refuse to File an application, and then 10 months for the review). Hence, we have a potential hiatus in any insulin approvals that reference currently approved insulins

\footnotetext{
${ }^{2}$ USAN, administered by the AMA, usually match the INN, which are administered by the World Health Organization and available worldwide.
} 
through early 2021 unless they are already well into review. Originator insulin applications face similar preclusions.

If a sponsor seeks an interchangeable designation concurrently in the initial filing, the review is within that same 12 months for the evaluation of the biosimilar. If subsequent to the initial filing, and including clinical data from switching studies (which is expected-see the FDA's new final guidance on interchangeability [30]), then an additional supplemental application with a 6-month review occurs and a further fee is incurred. Either way, an interchangeability designation can only be pursued for a product already designated biosimilar. Since no insulin product will be biosimilar on 23 March 2020, no interchangeable designation can be pursued, not even for those currently approved under Section 505(b)(2) for which a therapeutic equivalence designation could already have been sought. Consequently, the rolling over of the current biologics is likely to delay the availability of interchangeable insulin products.

\section{Conclusions}

The insulins are an exemplar of the rollovers, but they are not the only products affected-although they will likely impact the greatest number of patients. That products already approved as safe and effective if used as indicated must now fit into a different regulatory regime of safety, purity, and potency need not be a problem with careful planning. However, the potential for patient confusion, and uncertainty by their healthcare providers, means that the FDA educating all impacted stakeholders is going to be extremely important to public health. It is wise that the nonproprietary names will not change, even though that belies the need for suffixes on any other biologic [31-33]. The need to reconcile the information seen by patients on their medicines with that recorded in formal medical records and drug tracing systems is clear. Done well, this can ensure a smooth rollover with minimal interruptions in supply or reasons for patient concern. It is not clear that these needs are yet fully considered and that contingency plans have been put in place. That the insulin products themselves will not change pre- and post the rollover date of 23 March 2020 is key. Nonetheless, we fear that competition and access will be challenged rather than facilitated by their change in status in the USA from 'drugs' to 'biologics'.

\section{Compliance with Ethical Standards}

Conflict of interest KG and GW are employees of Avalere Health and work with multiple stakeholders in healthcare, including, but not limited to, biopharma companies (originator and generic), health insurance plans, providers, and patients' groups. GW is a volunteer member of the USP Nomenclature and Labeling Expert Committee.
Funding KG and GW are employees of Avalere Health. The authors retained editorial control.

Open Access This article is distributed under the terms of the Creative Commons Attribution-NonCommercial 4.0 International License (http://creativecommons.org/licenses/by-nc/4.0/), which permits any noncommercial use, distribution, and reproduction in any medium, provided you give appropriate credit to the original author(s) and the source, provide a link to the Creative Commons license, and indicate if changes were made.

\section{References}

1. WHO. Diabetes fact sheet. https://www.who.int/news-room/factsheets/detail/diabetes. Accessed 16 Jul 2019.

2. CDC. National diabetes statistics report, 2017. Estimates of diabetes and its burden in the United States. https://www.cdc.gov/ diabetes/pdfs/data/statistics/national-diabetes-statistics-report.pdf. Accessed 16 Jul 2019.

3. FDA. Statement from FDA Commissioner Scott Gottlieb, M.D., on the agency's continued efforts to bring competition to the insulin market to lower prices and expand access. 2 Apr 19. https:// www.fda.gov/news-events/press-announcements/statement-fdacommissioner-scott-gottlieb-md-agencys-continued-efforts-bring -competition-insulin. Accessed 16 Jul 2019.

4. FDA. Free publications for women: insulin. https://www.fda. gov/consumers/free-publications-women/insulin. Accessed 16 Jul 2019.

5. Dudzinski DM. Reflections on historical, scientific, and legal issues relevant to designing approval pathways for generic versions of recombinant protein-based therapeutics and monoclonal antibodies. Food Drug Law J. 2005;60(2):143-260.

6. Tirumalai G, Long A. United States Pharmacopeial Convention: respecting the past, moving confidently into the future. http:// www.histpharm.org/ISHPWG\%20USA.pdf. Accessed $18 \mathrm{Jul}$ 2019.

7. Drugs@FDA. Humulin N (insulin susp isophane recombinant human), NDA 018781, first approved 28 Oct 1982. https://www. accessdata.fda.gov/scripts/cder/daf/index.cfm?event=overview. process $\& A p p 1 N o=018781 \mathrm{https}: / / \mathrm{www}$. accessdata.fda.gov/scrip ts/cder/daf/index.cfm Accessed 16 Jul 2019.

8. FDA. Approved drug products with therapeutic equivalence evaluations (the "Orange book"). 39th ed. FDA; 2019. p. 493. https:// www.fda.gov/media/71474/download. Accessed 16 Jul 2019.

9. Drug Price Competition and Patent Term Restoration Act of 1984 (Hatch Waxman Act). https://www.gpo.gov/fdsys/pkg/STATU TE-98/pdf/STATUTE-98-Pg1585.pdf. Accessed 16 Jul 2019.

10. Patient Protection and Affordable Care Act [PPACA or ACA], title VII: Biologics Price Competition and Innovation Act of 2009 (BPCIA). https://www.fda.gov/media/78946/download. Accessed $16 \mathrm{Jul} 2019$.

11. Federal Register Notice. Interpretation of the "Deemed To Be a License" provision of the Biologics Price Competition and Innovation Act of 2009; guidance for industry; availability. 12 Dec 2018. https://www.federalregister.gov/documents/2018/12/12/201826854/interpretation-of-the-deemed-to-be-a-license-provisionof-the-biologics-price-competition-and. Accessed 16 Jul 2019.

12. Statement from FDA Commissioner Scott Gottlieb, M.D., on new actions advancing the agency's biosimilars policy framework. 11 Dec 2018. https://www.fda.gov/news-events/press-announceme nts/statement-fda-commissioner-scott-gottlieb-md-new-actionsadvancing-agencys-biosimilars-policy. Accessed 16 Jul 2019. 
13. FDA Draft Guidance. The "Deemed to be a License" provision of the BPCI Act: questions and answers; draft guidance for industry. https://www.fda.gov/media/119274/download. Accessed 16 Jul 2019.

14. FDA Draft Guidance. The "Deemed to be a License" Provision of the BPCI Act Questions and Answers Draft Guidance for Industry-Federal Register Notice. https://s3.amazonaws.com/publi c-inspection.federalregister.gov/2018-26855.pdf. Accessed 16 Jul 2019.

15. Federal Register. FDA hearing. The future of insulin biosimilars: increasing access and facilitating the efficient development of biosimilar and interchangeable insulin products; public hearing; request for comments. Federal Register Notice of 3 Apr 2019. https://www.federalregister.gov/documents/2019/04/03/201906438/the-future-of-insulin-biosimilars-increasing-access-andfacilitating-the-efficient-development-of. Accessed 16 Jul 2019.

16. FDA. Preliminary list of approved NDAs for biological products that will be deemed to be BLAs on March 23, 2020 (current as of May 31, 2018). https://www.fda.gov/media/119229/download. Accessed 16 Jul 2019.

17. FDA. Final guidance. Considerations in demonstrating interchangeability with a reference product. May 2019. https://www. fda.gov/media/124907/download. Accessed 1 Aug 19.

18. Sandow J, Landgraf W, Becker R, Seipke G. Equivalent recombinant human insulin preparations and their place in therapy. Eur Endocrinol. 2015;11(1):10-6.

19. Landgraf W, Sandow J. Recombinant human insulins-clinical efficacy and safety in diabetes therapy. Eur Endocrinol. 2016;12(1):12-7.

20. Drugs@FDA—search on "Insulin" for a list of all insulins approved in the US. https://www.accessdata.fda.gov/scripts/cder/ daf/index.cfm. Accessed 1 Aug 2019.

21. FDA. Combination product definition combination product types. https://www.fda.gov/combination-products/about-combinatio n-products/combination-product-definition-combination-produ ct-types. Accessed 16 Jul 2019.

22. USP-NF. Publication \& comment schedule. USP42-NF37. https ://www.uspnf.com/publication-comment-schedule. Accessed 16 Jul 2019.

23. World Health Organization. International Nonproprietary Names. https://www.who.int/medicines/services/inn/en/. Accessed $16 \mathrm{Jul}$ 2019.

24. American Medical Association. United States Adopted Names (USAN). https://www.ama-assn.org/about/united-states-adoptednames/usan-council. Accessed 18 Jul 2019.
25. USP National Formulary. https://www.uspnf.com/. Accessed 18 Jul 2019.

26. FDA. Revised draft guidance. Nonproprietary naming of biological products: update guidance for industry. 8 Mar 2019. https:// www.fda.gov/regulatory-information/search-fda-guidance-docum ents/nonproprietary-naming-biological-products-update-guida nce-industry. Accessed 16 Jul 2019.

27. McCamish M, Gallagher AM, Orloff J. Biosimilar by name and biosimilar by nature. RPM Report $2013 \mathrm{Jul} /$ Aug. https:// www.sandoz.com/sites/www.sandoz.com/files/rpm-report.pdf. Accessed 16 Jul 2019.

28. Pink Sheet. Woodcock: concerns about US FDA's biosimilars suffix policy detached from reality. 20 Mar 19. https://pink.pharm aintelligence.informa.com/PS124962/Woodcock-Concerns-About -US-FDAs-Biosimilars-Suffix-Policy-Detached-From-Reality. Accessed 16 Jul 19.

29. FDA. Draft guidance. 03-Guidance for industry_new and revised draft Q\&As on biosimilar development and the BPCI Act (Revision 2). Page 3, Footnote 4. https://www.regulations.gov/docum ent?D=FDA-2011-D-0611-0066. Accessed 16 Jul 2019.

30. Federal Register Notice. Considerations in demonstrating interchangeability with a reference product; guidance for industry; availability. 14 May 2019. https://www.federalregister.gov/docum ents/2019/05/14/2019-10001/considerations-in-demonstratinginterchangeability-with-a-reference-product-guidance-for-indus try. Accessed 1 Aug 19.

31. Regulations.gov. Comment from Federal Trade Commission. FTC docket submissions FDA-2013-D-1543-0146. 29 Oct 2015. https ://www.regulations.gov/document?D=FDA-2013-D-1543-0146. Accessed 1 Aug 2019.

32. Regulations.gov. Comment from Federal Trade Commission. FTC docket submissions FDA-2013-D-1543-0252. 9 May 2019. https ://www.regulations.gov/document?D=FDA-2013-D-1543-0252. Accessed 1 Aug 2019.

33. Federal Trade Commission. Comment of the staff of the Federal Trade Commission submitted to the Food and Drug Administration, Department of Health and Human Services in response to a request for comments on FDA's guidance for industry on the "Nonproprietary Naming of Biological Products; draft guidance for industry; update". Submitted on May 6, 2019. https://www. ftc.gov/system/files/documents/advocacy_documents/ftc-staff -comment-fda-department-health-human-services-its-updatedguidance-industry-nonproprietary/ftc_comment_to_fda_2019_ biologics_naming_guidance_5-6-19.pdf. Accessed 1 Aug 2019. 